References

Stewart, J. W. (1964) The earlier Gardar igneous rocks of the Ilímaussaq area, South Greenland. Unpublished Ph. D. thesis, Durham University.

Upton, B. G.J. (1962) The geology of Tugtutôq and neighbouring islands, South Greenland, Part I. Medd. Grфnland, Bd.169, Nr.8.

(1964) The geology of Tugtutô and neighbouring islands, South Greenland. Part III. Olivine gabbros, syeno-gabbros and anorthosites. Medd. Grфnland, Bd.169, Nr.3.

Ussing, N. V. (1912) The geology of the country around Julianehaab, Greenland. Medd. Grønland, Bd. 38.

\author{
PETROLOGICAL STUDIES OF SOME ALKALIC \\ AND PERALKALIC DYKE ROCKS FROM THE \\ TUGTUTÔQ-NARSSAQ AREA
}

\title{
R. Macdonald
}

The purpose of current research work on the dyke rocks and, to a lesser extent, the major Gardar intrusions of Tugtutôq and adjacent areas, is to elucidate more fully the development of the peralkine comenditic magmas. The dyke swarm through the Tugtutô region is instructive as it displays an apparently continuous series of rock-types from relatively basic microsyenites (or trachytes) to peralkalic microgranites (or comendites). The most basic rocks studied in this series are augite-fayalite microsyenites containing neither modal quartz nor normative aegirine. In more differentiated members of the swarm amphiboles of the hastingsite series become the dominant ferromagnesian minerals and modal quartz appears as an interstitial constituent. The hastingsitic amphiboles show some continuous zoning but give way abruptly with further differentiation to members of the riebeckite-arfvedsonite series. The trachytic rocks containing riebeckite-arfvedsonites show acmite in their norms and may be considered as peralkalic (in Shand's sense). With more extreme differen- 
tiation the quartz-feldspar-riebeckite-arfvedsonite assemblage becomes unstable and acmitic aegirine commences crystallisation. Coincidentially with the appearance of aegirine in the mode, sodium metasilicate becomes a normative component. In the most extreme fractionates aegirine is the sole ferromagnesian mineral.

However, some of the microgranitic rocks differ in containing an excess of $\mathrm{Al}_{2} \mathrm{O}_{3}$ over alkalies and are corundum normative. At least one acid dyke contains the 'calc-alkaline' assemblage of Qz-Fspar-MuscoviteChlorite. The possibility is being examined that these aberrant acid rocks were formed either :-

a) by fractionation of sodic ferromagnesian minerals leading to relative concentration of alumina, or

b) as a result of loss of alkalies relative to alumina, (perhaps by metasomatic passage into the country rocks).

The more basic microsyenites appear to be aphyric, except perhaps for sparse apatite phenocrysts, and to have been intruded in an almost wholly liquid condition. However in the quartz-bearing dykes feldspar phenocrysts are invariably present. Although the composition of the feldspar phenocrysts is being investigated, the existing data (Upton, 1964) suggests that they are normally more potassic than the liquids from which they crystallised. If this is general, there is some probability that the "orthoclase effect" described by Bailey and Schairer (1966) has been operative in the evolution of the residual per-sodic magmas.

Phenocrysts of (ferro-(?)) augite are found in some of the more basic quartz microsyenites which lack acmite in the norm. There appears to be a considerable temperature interval during which pyroxenes were not stable, separating the period in which ferro-augitic crystals were forming from that in which aegirine precipitates. Aggregates of aegirine are seen in some of the more advanced differentiates, apparently replacing original riebeckitearfvedsonite phenocrysts. Aegirine itself, however, is never seen as a "primary" phenocryst phase.

In some quartz microsyenites containing hastingsitic amphibole can be seen scattered crystals of amphibole which are smaller than the distinct phenocryst phases such as feldspar, but are larger than the groundmass amphibole. Whether these are microphenocrysts (i.e. inferring that they had formed before dyke intrusion) or merely large groundmass minerals cannot be determined from the textural evidence. In the microgranites, 
definite amphibole phenocrysts of the riebeckite-arfvedsonite series are common.

Quartz phenocrysts are almost ubiquitous thrcughout the porphyritic members of the microgranite series, but one or two of the very aegirinerich dykes carry only feldspar as a phenocryst phase. This may be due either to resorption of the quartz phase or to a coincidence of chilling of the magma before the feldspar-quartz boundary curve had been reached.

It is hoped to determined the composition of the major phenocryst minerals, and the thesis that fractionation of these phases could produce the observed trends of liquid compositions will be examined.

At Niaqornaq on the island of Qarmánguit timât some nepheline-bearing microsyenite dykes have been found; this is of interest since formerly no undersaturated dykes have been found in the mid-Gardar dyke swarm of the Tugtutôq area. Furthermore, it is suspected that more undersaturated dykes were collected during the summer of 1966, although this requires petrographic confirmation.

In the quartz-poor microsyenites, cooling was evidently slow enough to allow the development of an even holocrystalline granular texture. Glass has not been recorded from such rocks. With increasing richness in alkalinity and in quartz content, increasing degrees of supercooling seem to have characterised the dykes, and the quartz-rich microsyenites and the microgranites are commonly largely glassy. The spectacular flow, spherulitic, and complex devitrification textures which these dykes exhibit are being examined.

Some of the Central Complex syenites and granites have been studied in order to compare rocks of similar composition to those of the dyke swarm but which formed under more nearly plutonic conditions. This aspect of the work has been mainly geochemical, as the petrography has been dealt with fully by Upton (1964).

Field observations suggest that there has been little or no metasomatic alteration of host rocks by the various alkaline intrusions of the Tugtutôq area; by contrast the intrusion of the Kungnat complex has been responsible for fairly extensive metasomatism of wall rocks. It is possible, therefore, to contrast the complexes as "open" and "closed" systems. This is of importance with regard to the suggestion of Bailey and Schairer (1966) that slow-cooling peralkaline granites may readily lose soluble alkali silicates and other fugitives. It is intended to derive some semi-quantitative estimate of this type of alkali loss. 
It is hoped that the study of the three rock-suites, plus consideration of the data available for the other Gardar intrusives, will allow some comment to be made on the relationships between aegirine, riebeckite, astrophyllite and aenigmatite, the four principal "peralkaline" ferromagnesian minerals.

The study is being carried out at the University of Edinburgh as part of a Ph. D. studentship, under the supervision of Dr. B. G. J. Upton.

References

Bailey, D. K. , and Schairer, J. F. (1966) The system $\mathrm{Na}_{2} \mathrm{O}-\mathrm{Al}_{2} \mathrm{O}_{3}-\mathrm{Fe}_{2} \mathrm{O}_{3}-\mathrm{SiO}_{2}$ at 1 atmosphere and the petrogenesis of alkaline rocks. J. Petrol., Vol. 7, 114-170.

Upton, B. G. J. (1964) The geology of Tugtutôq and neighbouring islands, South Greenland. Part II. Nordmarkitic syenites and related alkaline rocks. Medd. Grфnland, Bd.169, Nr.2.

\section{REPORT ON THE SURVEY OF BERYLLIUM, NIOBIUM, URANIUM AND THORIUM MINERALIZATION IN THE ILÍMAUSSAQ COMPLEX, SOUTH GREENLAND}

\section{John Hansen}

A survey of uranium, thorium and niobium mineralization in the Ilímaussaq alkaline intrusion which was started in 1964 was extended in 1965 to include a survey of beryllium mineralization. This was continued during 1966 .

The Ilímaussaq complex is an intrusion dominantly built up of an early augite syenite followed by nepheline syenites (an agpaitic suite consisting. mainly of naujaites, kakortokites and lujavrites).

The beryllium minerals are generally found in late hydrothermal veins consisting of albite, analcime, natrolite and ussingite, but are also found disseminated in the naujaite especially where it is albitized. These veins are from less than one millimetre to $2 \mathrm{~cm}$ wide. Most of the veins are found in 